\title{
2 Noise in the Cretaceous Quiet Zone uncovers plate tectonic chain
}

\section{3 reaction}

4 Authors: Derya Gürer ${ }^{1,2}$, Roi Granot ${ }^{3}$, Douwe J J van Hinsbergen ${ }^{1}$

$5 \quad{ }^{1}$ Department of Earth Sciences, Utrecht University, 3584 CD Utrecht, The Netherlands

$6 \quad{ }^{2}$ School of Earth and Environmental Sciences, University of Queensland, St. Lucia, QLD 4072, Australia

$7 \quad{ }^{3}$ Department of Earth and Environmental Sciences, Ben-Gurion University of the Negev, Beer-Sheva

$8 \quad 84105$, Israel

9 e-mails: derya.guerer@uq.edu.au,rgranot@bgu.ac.il,d.j.j.vanhinsbergen@uu.nl

10 Twitter: @geoceanic (Derya Gürer), @vanHinsbergen (Douwe van Hinsbergen)

This manuscript is a non-peer reviewed preprint submitted to EarthArXiv.

Manuscript under consideration at Nature Geoscience

Original submission date: 13th May 20 


\section{Noise in the Cretaceous Quiet Zone uncovers plate tectonic chain}

\section{reaction}

Derya Gürer ${ }^{1,2}$ *, Roi Granot ${ }^{3}$, Douwe J J van Hinsbergen ${ }^{1}$

Global plate reorganizations, intriguing but loosely defined periods of profoundly changing plate motions, may be caused by a single trigger such as a continental collision or a rising mantle plume. But whether and how such triggers propagate throughout a plate circuit remains unknown. Here, we show how a rising mantle plume set off a 'plate tectonic chain reaction'. Plume rise has been shown to trigger formation of a subduction zone within the Neotethys Ocean between Africa and Eurasia at 105 Ma. We provide new constraints on Africa-Eurasia convergence rates using variations in geomagnetic 'noise' within the Cretaceous Normal Superchron (the 126-83 Ma period without magnetic reversals) recorded in the Atlantic Quiet Zones crust. These new constraints are consistent with the timing of numerically predicted African Plate acceleration and deceleration associated with onset and arrest of the intra-Neotethyan subduction zone. The acceleration was associated with a change in Africa-Eurasia convergence direction, which in turn was accommodated by a next subduction initiation at $\sim 85$ Ma in the Alpine region that cascaded into regional tectonic events. Our concept of plate tectonic chain reactions shows how changes in plate motion, underpinned by mantle dynamics, may self-perpetuate through a plate circuit, making global plate reorganizations a key to unlock the driving mechanisms behind plate tectonics.

\section{Pronounced changes in the velocity and/or direction of tectonic plate motions are short-lived events} punctuating long periods of gradually evolving motion ${ }^{1-3}$. Inspection of global plate kinematic models and of geological records at plate boundaries have led to the hypothesis that plate motion changes are at times concentrated in 'global plate reorganizations': short-lived but ill-defined periods of $\sim 10$ Ma in 
51 which plate motions change across the globe. Such reorganizations, for instance in the mid-Cretaceous around $105 \mathrm{Ma}^{2-4}$ or in the Eocene, around $50 \mathrm{Ma}^{5-8}$, are suspected to be triggered by geodynamic coincidences such as rising mantle plumes ${ }^{2}$, collisions $^{2-5}$, or ridge subduction ${ }^{6-8}$. But to set off a global plate reorganization, plate motion changes induced by such isolated dynamic triggers must be able to cascade to neighbouring plates, for which a mechanism has so far not been identified.

We hypothesize that when a trigger causes a plate motion change, this change may in turn trigger subsequent plate motion changes, in what we conceptualize as a 'plate tectonic chain reaction'. Geodynamic analysis has long identified that the main drivers of plate motion are the negative buoyancy of subducted lithosphere (slab pull), and occasional short-lived and subtle effects of spreading mantle plume heads below the lithosphere (plume push $^{9-11}$ ). Formation of new, or the abandonment of preexisting plate boundaries (mid-oceanic ridges or subduction zones), at times combined with the arrival of mantle plumes, are thus widely regarded to form the dynamic underpinning of observed plate motion changes ${ }^{7,9-15}$. Initiation of subduction of a plate, either spontaneously ${ }^{16}$ or forced (for instance by ridge subduction $^{7,17}$, or by arrest, relocation, or reversal of subduction) will change where and on which plates slab pull is exerted ${ }^{14}$. The onset or cessation of a slab pull force after initiation or arrest of subduction is, in turn, a logical driver of plate acceleration or deceleration, respectively ${ }^{7,13,14,17}$. Hence, while initiation of a new subduction zone may respond to an initial trigger, for instance plume push ${ }^{18,19}$, such initiations may also be forced by (the dynamic processes underlying) cascading plate motion changes. Subduction initiation events may thus form the links making plate tectonic chain reactions possible.

Recently, the study of ophiolites in Oman and Anatolia revealed that the formation of an intra-oceanic subduction zone around 105 Ma was forced by far-field stress changes ${ }^{18}$. This subduction zone formed in the Neotethys Ocean in the modern eastern Mediterranean region and continued to the western Indian Ocean, where it transitioned into a spreading ridge between India and Madagascar ${ }^{11}$. Its formation is proposed to result from the push of the Morondava plume head (Fig. 1b) causing a India-Africa plate motion change at $\sim 105 \mathrm{Ma}^{11}$. By 96-92 Ma, this subduction zone developed sufficient slab pull to drive upper plate extension widely recorded in the age of the crust of supra-subduction zone ophiolites from the 
Mediterranean region to Oman and Pakistan ${ }^{18}$. Because forced initiation and development of significant slab pull are separated by $\sim 10 \mathrm{Ma}$, this provides the opportunity to separate the dynamic causes from the consequences of this subduction zone, making this the ideal test case to evaluate the plausibility of plate tectonic chain reactions. To identify potential causes of subduction initiation, we explore kinematic predictions of generic numerical models to evaluate whether this onset of slab pull may in turn have been a trigger of a subsequent plate motion change, and whether this change caused another plate boundary reorganization, thus defining a chain reaction. But to do this, required overcoming a notorious problem: the absence of plate kinematic constraints during the Cretaceous Normal Superchron (CNS), the 126-83 $\mathrm{Ma}^{20}$ period without magnetic polarity reversals expressed in the oceanic Cretaceous Quiet Zone (CQZ) crust. Therefore, we calculated the first Africa-Eurasia kinematic plate model for the CNS using recently identified magnetic intensity variations on the Atlantic CQZs ${ }^{21}$. This paved the path to analyze the dynamic propagation of plate tectonic chain reaction, that may be part of the enigmatic Cretaceous plate reorganization.

\section{Global plate reorganizations and proposed triggers}

The two most widely discussed global plate reorganizations are the Cretaceous $(\sim 105-100 \mathrm{Ma})^{2}$ and Eocene $(\sim 55-45 \mathrm{Ma})^{5}$ plate reorganizations. The Cretaceous reorganization, during the CNS, was inferred based on changes in the Atlantic, Indian, and northern Pacific fracture zone orientations ${ }^{2}$. The age was loosely estimated based on interpolation of seafloor spreading rates, and further defined by inspection of tectonic events recorded in continental geological records across the globe in the 110-90 Ma time period ${ }^{2}$. Tectonic shortening in western North America and East Asia, subduction along western South America, extension in Antarctica and Australia, and basin instability in Africa and Europe were all used to identify this reorganization ${ }^{2}$. Proposed triggers include cessation of subduction along the east Australian-New Zealand margin due to collision of the Hikurangi oceanic plateau ${ }^{2}$, the rise of the Bouvet mantle plume in the South Atlantic Ocean², collision between microcontinents in Tibet $^{4}$, and the formation of an Andean- 
102 style subduction zone along continental Eurasia ${ }^{3}$. But how these triggers would have propagated to cause 103 changes ascribed to the reorganization remains undefined.

104 Similar to the Cretaceous reorganization, the Eocene plate reorganization is hypothesized based on a series of plate kinematic changes across the globe including the Pacific plate motion change reflected by the prominent change in the Hawaii-Emperor seamount chain, the formation of subduction zones, midocean ridges, back-arc basins, and orogens ${ }^{5,8,22-26}$, yet it remains unclear whether this was the response to one single or multiple unrelated triggers, or how these kinematic changes dynamically propagated in space and time. Proposed drivers for all or part of the reorganization include initiation of Pacific Plate subduction, either spontaneously ${ }^{16}$, by ridge subduction ${ }^{7,8,17}$ or subduction polarity reversal ${ }^{14}$, collision of India and $\mathrm{Asia}^{5}$, collisions and subduction relocation in western North America ${ }^{27}$, and lower mantle subduction of slabs below South America ${ }^{28}$.

\section{Intra-Neotethyan subduction initiation: start of a tectonic chain reaction?}

We test our concept of a plate tectonic chain reaction through a case study of the initiation of a major intra-oceanic subduction zone in the Neotethys Ocean. During the mid-Cretaceous, an intra-oceanic subduction zone formed from a trench-trench-trench triple junction with a subduction zone that had already existed since Jurassic time along the southern Eurasian margin ${ }^{19,22}$ to the west Indian Ocean, where the plate boundary transitioned into a rift (and later ridge) that ended in a ridge-ridge-ridge triple junction in the Southern Ocean ${ }^{11}$. This initiation of the intra-Neotethyan subduction zone generated a socalled double, in-line subduction zone configuration between Africa and Eurasia and formed a new plate consisting predominantly of Neotethyan oceanic lithosphere ${ }^{23}$ (Fig. 1b). In the latest Cretaceous, the southern rim of this plate was emplaced onto continental crust of Greater Adria, Africa, and Arabia along the southern Neotethyan margin (black hatched area in Fig. 1c) and relics are today preserved as forearc supra-subduction zone ophiolites in the eastern Mediterranean region and along northeastern Arabia, and in melanges in suture zones ${ }^{22,24,25}$ (Fig. 1d). Geochemical and geochronological data show that the formation of oceanic crust of these ophiolites, due to upper plate extension and seafloor spreading above a 
nascent subduction zone (so-called 'supra-subduction zone ophiolites'), began by 96-95 Ma in Oman ${ }^{24}$ and $\sim 92 \mathrm{Ma}$ in the eastern Mediterranean region ${ }^{25}$. These observations demonstrate that by this time, slab pull in the new subduction zone was sufficient to rupture the upper plate, and must have exerted slab pull on the trailing African-Arabian Plate ${ }^{26,29}$. The initiation of the subduction zone itself predated upper plate extension, and was already underway by $104 \mathrm{Ma}$ as constrained by garnet Lu/Hf geochronology of metamorphic soles below the Neotethyan ophiolites ${ }^{18,30}$. This demonstrates that convergence initiating subduction predated upper plate extension, and must have been induced by a change in plate motion driven by far-field forcing ${ }^{18}$. Structural geological and paleomagnetic observations of metamorphic soles and supra-subduction ophiolitic crust suggested that incipient convergence was $\sim \mathrm{E}-\mathrm{W}$ directed, highly oblique to the southern Neotethyan passive margin ${ }^{26,31}$ (Fig.1b). The rise of the Morondava mantle plume below the southwest Indian Ocean was identified as the likely trigger: plume rise induced radial plume head spreading that triggered separation of India and Madagascar, whereby the cratonic keels of India and Africa acted as pivots around which the two plates underwent an opposite rotation causing E-W convergence in the Neotethys ${ }^{11}$. This convergence triggered subduction initiation parallel to the stepped continental margin of west India, Arabia, and Greater Adria ${ }^{11,22,26,31}$. Seismic tomographic images show that even though the convergence driving subduction initiation was highly oblique to the Arabian-Greater Adriatic margin, it led to a slab, now located in the mid-mantle below Arabia and the eastern Mediterranean region, that is broadly parallel to the Cretaceous south Neotethyan margin ${ }^{32}$. Along the African-Arabian margin, the intra-oceanic subduction zone - and hence the associated slab pull - ceased between the $\sim 85 \mathrm{Ma}$ first arrival of African/Arabian continental crust in the trench and cessation of ophiolite obduction by $\sim 70 \mathrm{Ma}^{22,33}$ (Fig. 1c).

To evaluate whether the inception of slab pull in the new subduction zone may have been a trigger for a subsequent plate motion change, we explore numerical models of subduction dynamics. The geometry of the double, in-line subduction zone configuration between Africa and Eurasia (Fig. 1b), which bears similarities to the Philippine Sea Plate today, has recently received considerable attention in the numerical modelling community, who predicted that the onset and arrest of double slab pull will generate 
154 pronounced plate accelerations and decelerations, respectively ${ }^{12,34-37}$. Convergence rates across coupled

155 double subduction systems are predicted to be significantly faster than across a single subduction

156 zone because of the significant slab pull exerted by two slabs working in tandem. Numerical models

157 suggest that this stronger pull occurs because plates are not decoupled, but appear to "communicate"

158 through the dynamic pressure build-up in the mantle between them ${ }^{34}$. Numerical models of double, in-

159 line subduction ${ }^{12,34-37}$ thus predict acceleration of Africa-Eurasia convergence rates around $\sim 96-92 \mathrm{Ma}$

160 due to onset of double-slab pull, and a deceleration sometime between $\sim 85$ and 70 Ma due to subduction

161 arrest along the Arabian margin. To test that prediction, however, we first need to overcome the crude

162 temporal resolution of the existing Africa-Eurasia plate kinematic models that stems from the lack of

163 geomagnetic field reversals during the CNS.

\section{Revised Africa-Eurasia plate kinematic model}

Past Africa-Eurasia relative plate motions are calculated from restoring the opening of the Central and North Atlantic Oceans through the Africa-North America-Eurasia plate circuit (Figs. 1 and 2). Previous reconstructions ${ }^{38,39}$, without any kinematic constraints within the CQZ and without quantified uncertainties, proposed that Africa moved eastward with respect to Eurasia during the Early Cretaceous and later rotated northward, sometime during the Cretaceous. These studies also suggested that Africa-

171 Eurasia convergence rates since the Mesozoic have mostly been stable and small $\left(<20 \mathrm{~mm} \mathrm{yr}^{-1}\right)$. Importantly, the lack of geomagnetic polarity reversals between $\sim 126$ and $83.6 \mathrm{Ma}^{20}$ (i.e., CNS, see Methods for discussion of the time scale), provides a major challenge for identifying the timing of the major counter clockwise rotation of Africa relative to Eurasia, and its consequences on the evolution of convergence rates.

We present a revised Africa-Eurasia plate kinematic model that consists of rotation parameters (i.e., pole locations, angle of rotations and their uncertainties) for 15 time steps (i.e., magnetic anomalies) between 156 and $10 \mathrm{Ma}$, all of which are based on restoring conjugate sets of marine magnetic anomalies 
180

181

182

183

184

185

186

187

188

189

190

191

192

193

Africa-North America and North America-Eurasia (see Methods, Fig. 3, and Extended Data Tables 1 and

2). Next, we overcome the challenge of the lack of polarity reversals during the CNS by tracing two magnetic anomaly features $\left(\mathrm{Q} 1\right.$ and $\left.\mathrm{Q}^{21}\right)$ that result from prominent changes in the behaviour of the geomagnetic field (Fig. 2 and Extended Data Fig. 1). Their ages were inferred in the Central Atlantic CQZs by drill hole data and tectonic constraints at $\sim 92(\mathrm{Q} 1)$ and $\sim 108(\mathrm{Q} 2) \mathrm{Ma}^{21}$. Together with independent seafloor fabric constraints as well as fracture zone crossings, we computed new intra-CNS finite rotation parameters for Africa-North America motion for Q1 and Q2 and combined them with the North America-Eurasia rotations. The transition from continental rifting to seafloor spreading between North America and Eurasia occurred during the $\mathrm{CNS}^{40}$, and we cannot confidently identify Q1 or Q2 there. Our analysis assumes that during the CNS the North America-Eurasia motion as indicated by drill hole data and the relatively simple North Atlantic fracture zone orientations, was ultra-slow and stable compared to the motion of Africa relative to North America ${ }^{41}$, and combines the Africa-North America motion with the North America-Eurasia-interpolated rotation parameters for this time period (see

Methods). We note that due to the ultra-slow North America-Eurasia spreading rates this assumption has minor effects on the resultant Africa-Eurasia motions and associated uncertainties.

The new kinematic model (Fig. 3) implies that Africa convergence rates at the easternmost side of the

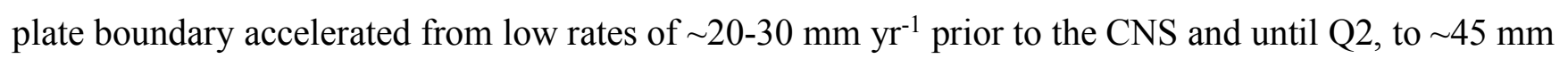
$\mathrm{yr}^{-1}$ averaged over the Q2-Q1 interval (108-92 Ma), followed by a spike at $\sim 70-80 \mathrm{~mm} \mathrm{yr}^{-1}$ between the Q1 and C33o (92-79.9 Ma) interval. The magnitude of plate acceleration decreases westwards illustrating that the acceleration coincided with the counter-clockwise rotation of Africa versus Eurasia (Fig. 3b-c). We note that the spike in convergence rate continued for a brief interval after the CNS (Anomalies C34C33o; 83.6-79.9 Ma), independently supporting the intra-CNS results. The spike was followed by a sharp deceleration at $\sim 80 \mathrm{Ma}$, after which the convergence rates (Fig. 3c) and the relative plate directions (Fig. 3b) remained relatively stable. 


\section{Manuscript submitted to Nature Geoscience}

The new plate kinematic constraints are consistent with numerical model predictions for plate kinematic response to double subduction zone inception and arrest $\mathrm{t}^{12,34-37}$. It is thus feasible that the acceleration of Africa-Eurasia convergence, and the associated and synchronous counter-clockwise rotation of Africa, is the dynamic response to the $\sim 96-92 \mathrm{Ma}$ onset of double slab pull. The double slab pull only affected the eastern half of the African plate and the counter-clockwise rotation of Africa is thus a logical response. The interpretation that plate motion change is the result of double slab pull is further supported by the coincidence of arrest of the intra-Neotethyan subduction zone between 85 and $70 \mathrm{Ma}^{22,33}$ (Fig. 1c) and the sharp decrease in convergence rates that we observe (Fig. 3c). This shows that the intraNeotethyan subduction zone that was induced from 104 Ma onward by a plume-induced clockwise rotation of Africa versus India ${ }^{11}$, became itself the driver of the next plate motion change upon inception of slab pull.

Interestingly, the CNS counter-clockwise rotation of Africa relative to Eurasia that we interpret as driven by the inception of slab pull (Fig. 3), induced convergence on a former transform fault in the western Mediterranean region. Prior to the rotation, Africa-Iberia and Africa-southern Europe motion was primarily accommodated along transform faults, but Africa-Eurasia counter-clockwise change in rotation induced slow convergence that sparked two subduction zones with opposite polarities, straddling from Iberia to the western $\mathrm{Alps}^{22}$ (Fig. 1). The oldest high-pressure metamorphic rocks associated with these new subduction zones, on Corsica ${ }^{42}$ and in the western $\mathrm{Alps}^{43}$, confirm that subduction was underway by $\sim 85 \mathrm{Ma}$. Because convergence rates associated with this subduction were slow $\left(<10 \mathrm{~mm} \mathrm{yr}^{-1}\right.$, Fig. 3) and much of the subducting lithosphere in the Alps was continental ${ }^{22}$, the inception of significant slab pull was long-delayed. For the northwest-dipping slab below Iberia (Fig. 4), roll-back finally led to the opening of a back-arc basin across the western Mediterranean region from $~ 30$ Ma onward ${ }^{44}$. Roll-back rates of the south-dipping slab in the western Alps never exceeded African plate advance, and both slabs were very narrow compared to the plates they were attached to. Thus, the dynamic changes they induced likely did not cause significant changes in Africa-Eurasia convergence, but were restricted to western Mediterranean back-arc basin opening ${ }^{44}$. Nonetheless, the chain reaction will likely continue: arrival of 
232 the North African lithosphere in the western Mediterranean trench led to subduction arrest some $15 \mathrm{Ma}$

$233 \mathrm{ago}^{22}$, and ongoing Africa-Europe convergence is in the process of causing a reversal of subduction

234 polarity, with Eurasian oceanic lithosphere starting to subduct below North Africa ${ }^{45}$ : inception of slab pull

235 may at some stage in the future drive the next dynamic response.

236 Through combining dynamic causes and effects predicted by physics-based modelling with

237 geologically documented kinematic evolution, we show that plate motion and plate boundary change

238 induced by one trigger may become the driver of a subsequent plate reorganization event. Such plate

239 tectonic chain reactions thus allow for long-term propagation of plate tectonic changes through a plate

240 circuit and provide an avenue towards a dynamic underpinning of intriguing yet hitherto enigmatic global

241 plate reorganizations. The plate tectonic chain reaction that we identify here propagated from a plate

242 reorganization induced by mantle plume rise in the southwest Indian ocean to active subduction initiation

243 in the western Mediterranean region over a time period of $\sim 100 \mathrm{Ma}$ (Fig. 4). We foresee that, on the one

244 hand, 'global' plate reorganizations ${ }^{5}$ may in fact be particularly rapid (i.e., within a few million years)

245 plate tectonic chain reactions initiated by a single trigger ${ }^{5,7}$ that sets off a cascade of geodynamic events

246 propagating through the global plate circuit. On the other hand, they may be a mere coincidence of

247 several regional chain reactions responding to multiple unrelated triggers. Our analysis illustrates how the

248 global plate circuit may be tied into self-perpetuating chain of events and paves the way towards a

249 mechanistic understanding of regional and global plate reorganizations.

251 Keywords

252 Africa-Eurasia convergence, plate kinematics, double subduction, plate reorganization, Neotethys, 253 Cretaceous Normal Superchron, Cretaceous quiet zone, Central Atlantic, marine magnetic anomalies

\section{Authors' information}

$256{ }^{1}$ Department of Earth Sciences, Utrecht University, 3584 CD Utrecht, The Netherlands

$257{ }^{2}$ School of Earth and Environmental Sciences, University of Queensland, St. Lucia, QLD 4072, Australia 
$258{ }^{3}$ Department of Earth and Environmental Sciences, Ben-Gurion University of the Negev, Beer-Sheva 25984105 , Israel

$260 *$ *e-mail: derya.guerer@uq.edu.au

\section{Acknowledgements}

263 RG acknowledges ISF grant 716/16. DJJvH acknowledges NWO Vici grant 865.17.001.

265 Authors' contributions

266 All authors contributed equally to the design of the research, the conduction of research, and the writing 267 of the paper.

\section{Competing interests}

270 The authors declare no competing interests. Correspondence and requests for materials should be

271 addressed to DG, derya.guerer@uq.edu.au 


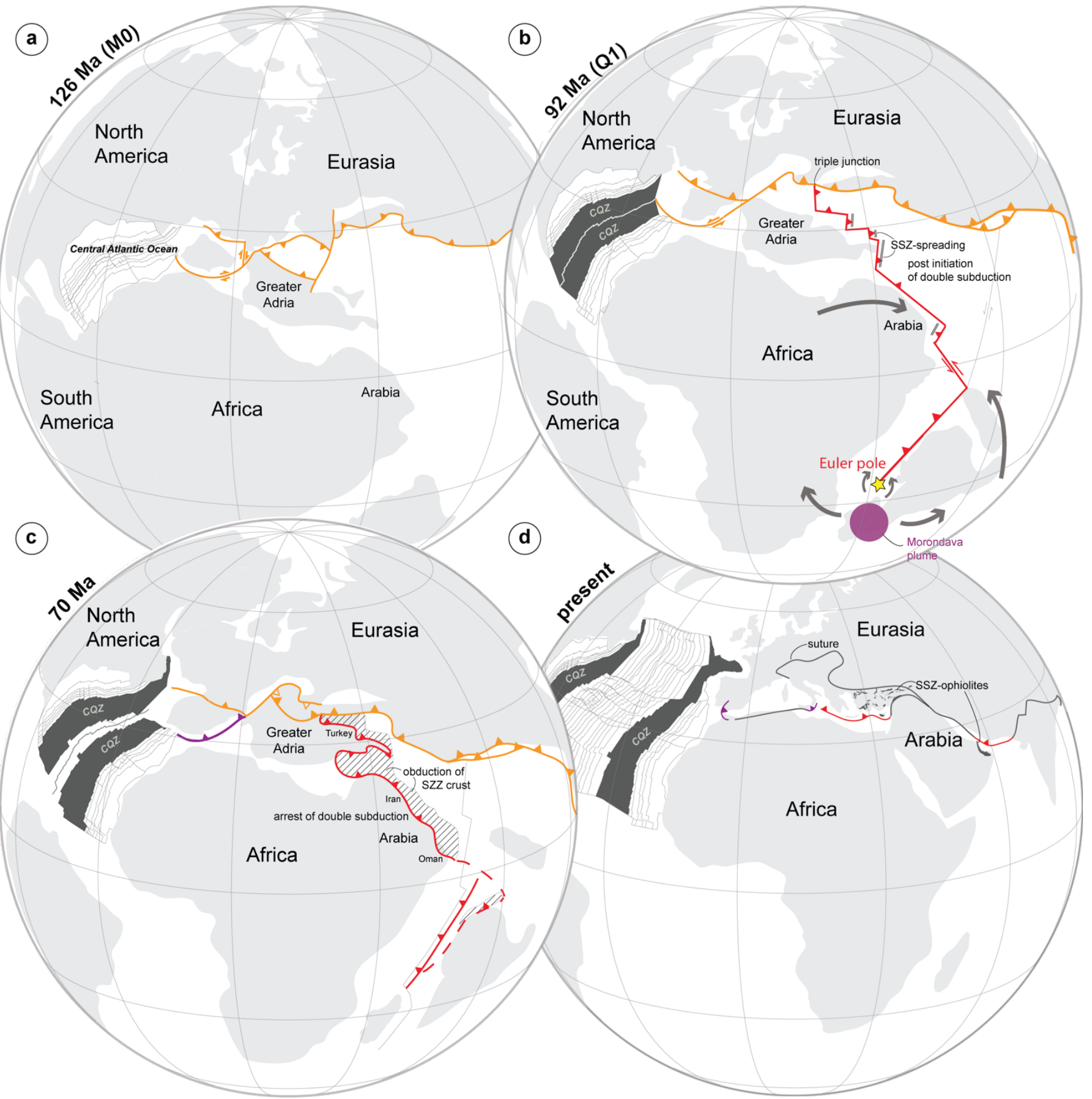

Figure 1. Plate boundary evolution of the Atlantic Ocean, updating previous reconstructions ${ }^{3}$ with our new constraints in the Neotethys between Africa and Eurasia at a) $126 \mathrm{Ma}$ (corresponding to Anomaly M0 - the onset of the Cretaceous Normal Superchron), b) $92 \mathrm{Ma}$ (corresponding to Q1, and around the onset of significant slab pull of the Neotethyan intra-oceanic subduction system recorded in eastern Mediterranean and Arabian ophiolites), triggered by the arrival of the Morondava plume ${ }^{11}$ c) $70 \mathrm{Ma}$ (corresponding to obduction of supra-subduction crust (hatched area) and arrest of subduction at the Neotethyan intra-oceanic subduction zone along Arabia and NE Africa), and the formation of a new 
subduction zone in the western Mediterranean (purple) and d) present-day configuration with distribution

281 of Neotethyan ophiolites. Reconstructions portrayed in a slab-fitted mantle reference frame ${ }^{46}$. See

282 Methods for details. Abbreviations: SSZ, supra-subduction; CQZ, Cretaceous quiet zone.

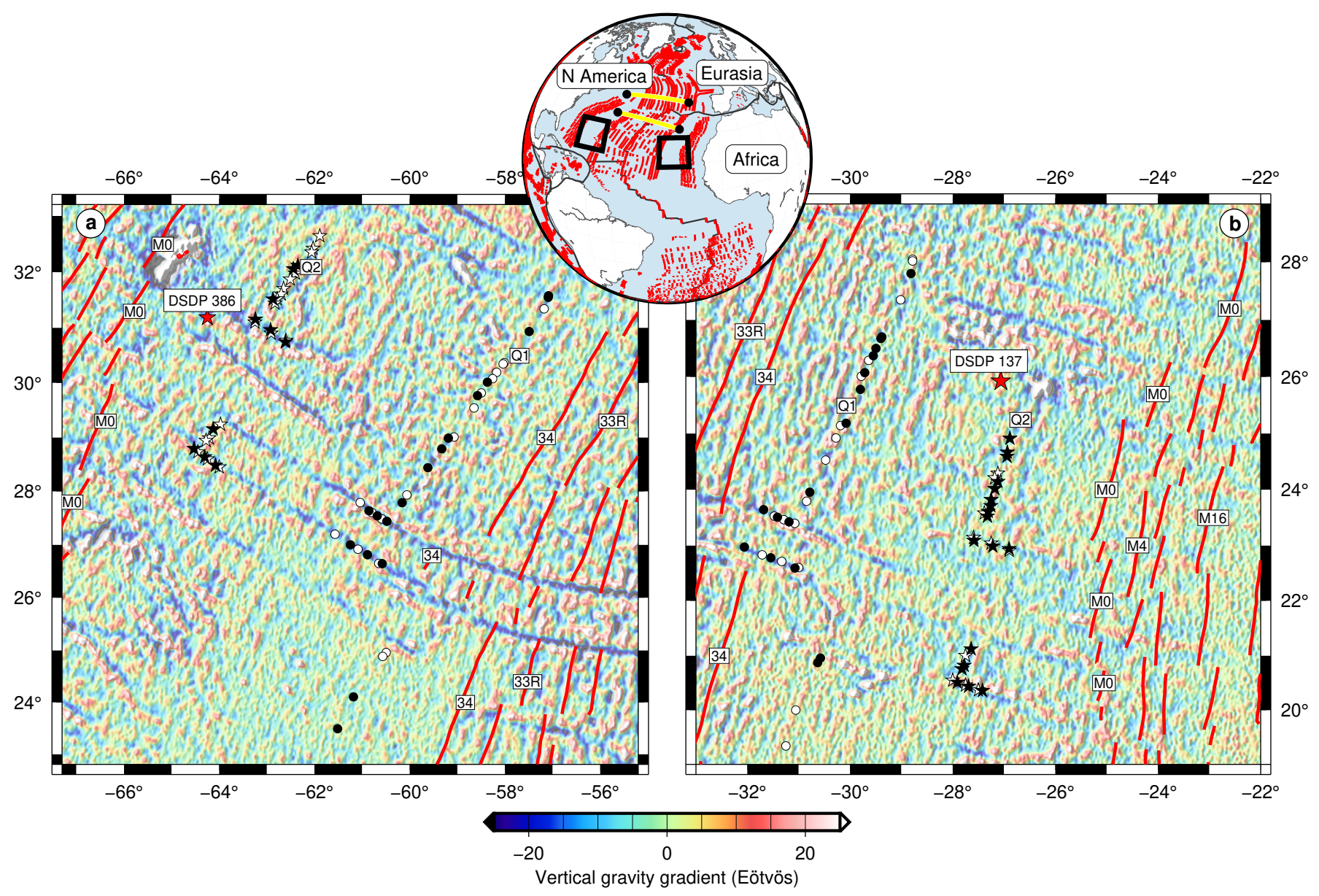

285 Figure 2. Central Atlantic Cretaceous quiet zones (a North America, b Africa) magnetic anomaly and

286 fracture zone picks that were used to compute Cretaceous Normal Superchron pole parameters (Q1,

287 circles; Q2, stars). White and black symbols delineate the location of the picks and reconstructed picks,

288 respectively (wiggle plots are shown in the Extended Data, Fig. 1). Magnetic isochrons are shown with

289 red lines. Locations of DSDP drill holes that were used to date Q1 and Q2 ${ }^{21}$ are marked by red stars.

290 Background is the seafloor fabric as delineated by the vertical gravity gradient grids derived from satellite

291 altimetry ${ }^{47}$. Note the curvature in fracture zone orientations found toward the young-end of the quiet

292 zones. Red lines mark locations of the reversals-related magnetic isochrons. Inset shows the Africa-North

293 America-Eurasia plate circuit (yellow lines). 


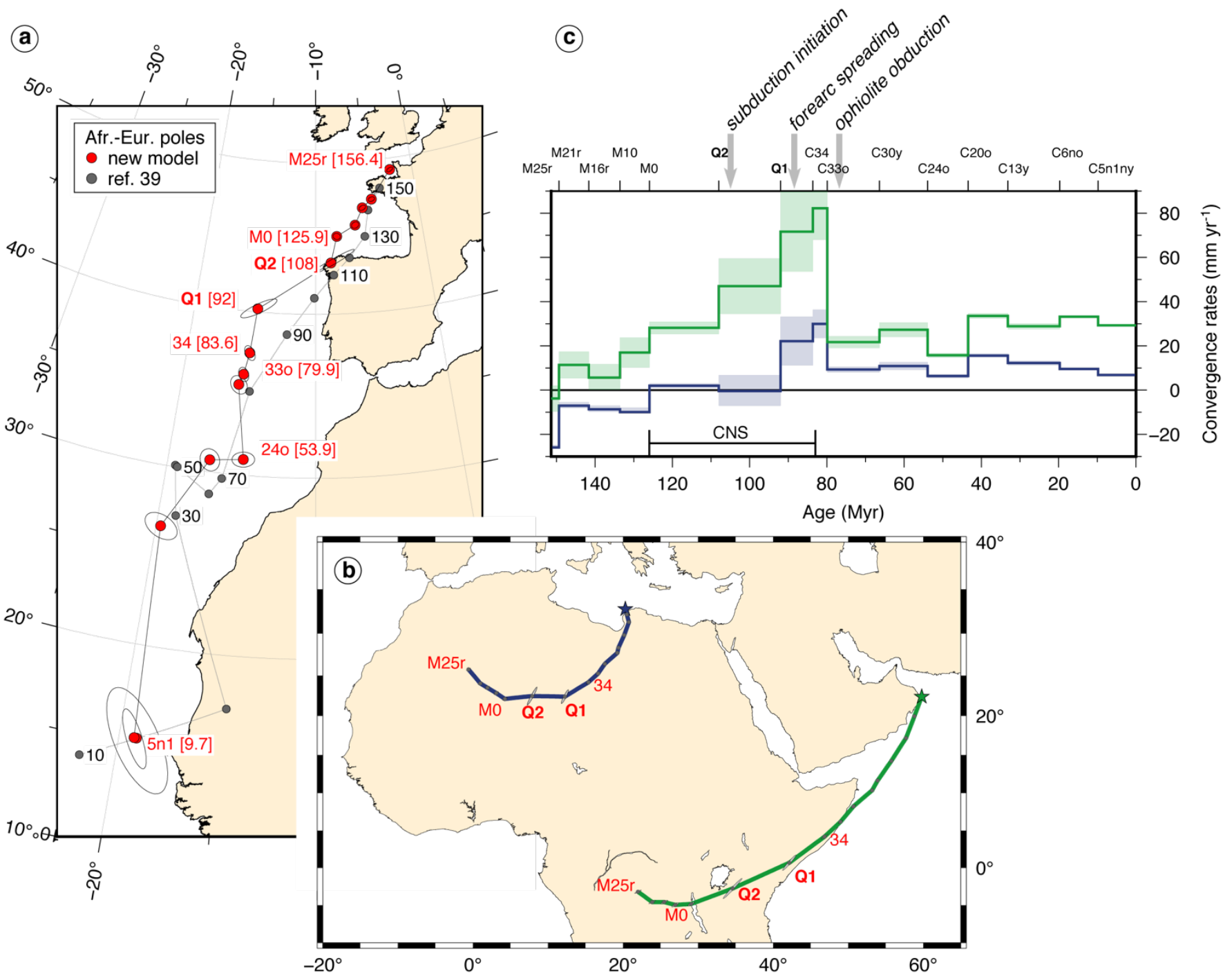

Figure 3. Africa-Eurasia relative plate motions since the Mesozoic. a. Location of Africa-Eurasia finite rotation poles (red circles) and their 95\% confidence ellipses. b. Predicted plate motion trajectories for the

297 African Plate relative to Eurasian Plate calculated based on our revised kinematic model. The western 298 trajectory (blue line) is based on Africa-Eurasia pole parameters whereas the eastern (green line) 299 trajectory also includes the Neogene Arabia-Africa motion (see Methods). Grey filled ellipses delineate 300 the $95 \%$ confidence locations. c. Convergence rates computed along the synthetic trajectories. Shadings 301 show the $1 \sigma$ uncertainties. Grey shadings indicate tectonic events. 


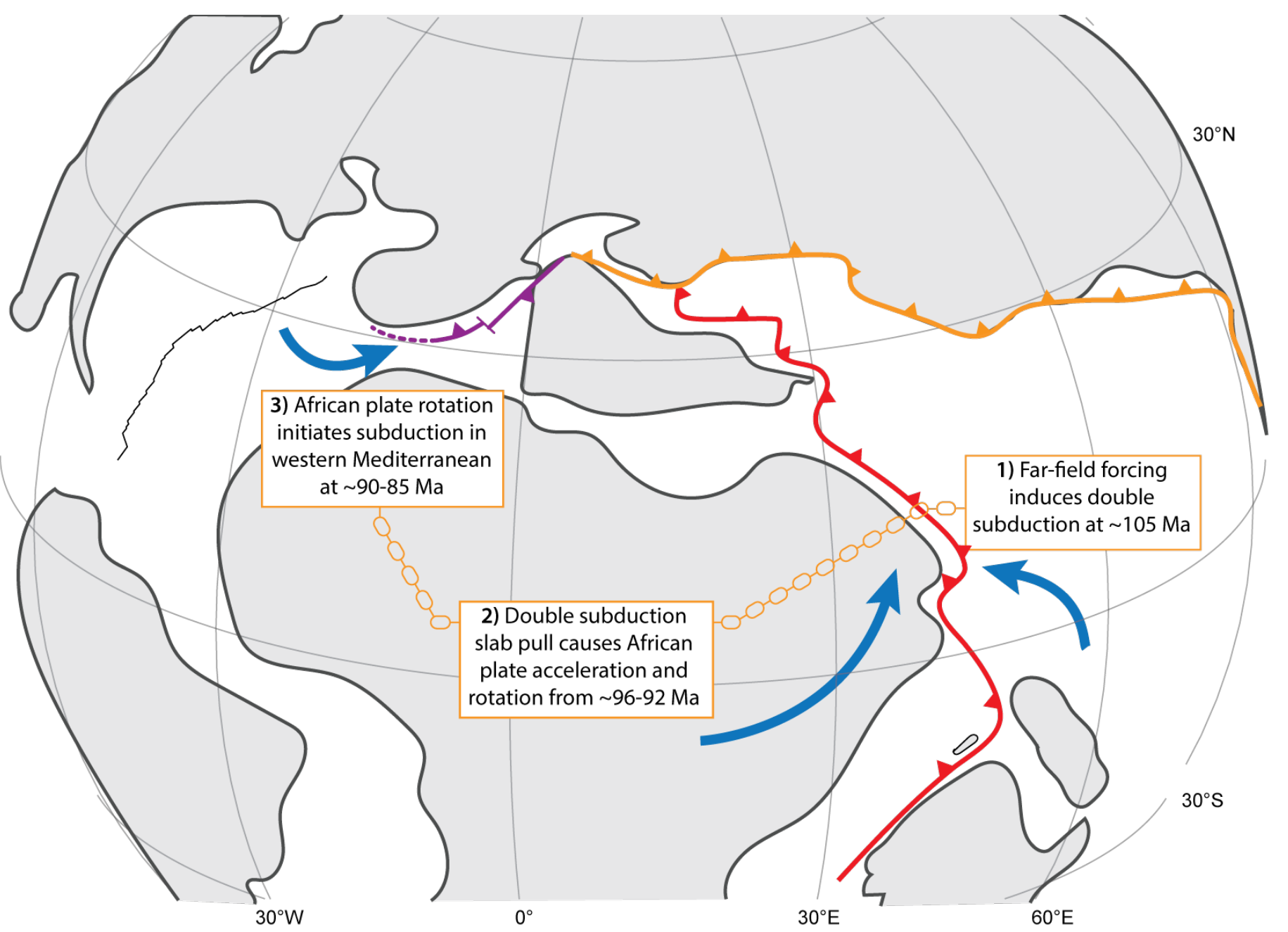

Figure 4. Chain of tectonic events in the Neotethys that lead to African-Eurasia plate motion changes as the dynamic response to 1) induced subduction initiation at $\sim 104 \mathrm{Ma}$, followed by 2) the $\sim 96-92 \mathrm{Ma}$ onset of African plate acceleration and rotation caused by double in-line slab pull, leading to 3) subduction initiation in the western Mediterranean at $\sim 90-85$ and finally, $\sim 85-70$ Ma arrest of double, in-line slab pull.

Methods

\section{Timescale}

314 We adopt the time scale of Gradstein et al. ${ }^{20}$ because it intercalibrated, among others, bio- and magnetostratigraphy. The onset of the CNS (i.e., Anomaly M0) in that timescale is assigned with the age 
316 of $\sim 126 \mathrm{Ma}$, but this age is rather uncertain and the actual age may in fact lay closer to $\sim 121 \mathrm{Myr}^{\mathrm{ago}}{ }^{4,48}$.

317 Because we compare geological events and reconstructions of the Neotethys, largely based on

318 biostratigraphic dating, with marine magnetic anomalies, our study requires an inter-calibrated timescale

319 explaining our choice for the Gradstein et al. ${ }^{20}$ timescale. We note that shifting the age of the base of the 320 CNS to 2121 Myr ago would have negligible effect on the convergence rates prior to Q1 (92 Ma ago) as 321 the direction of Africa-Eurasia relative plate motion nearly paralleled the margin at that time. The ages of 322 Q1 and Q2 were supported by dated oldest sediments from the ocean floor close to these anomalies 323 (DSDP sites 137 and 386, Fig. 2), and seafloor spreading model between Anomalies M0 and C34 ${ }^{21}$, and are thus only slightly (i.e., to within a $\sim$ million years) affected by the age of the base of the CNS.

\section{Neotethys reconstruction}

The paleo-tectonic map at 92 Ma ago shown in Fig. 1 is based on a systematic kinematic restoration of plate motions, orogenic deformation, and paleomagnetically-constrained rotations. Restoration of orogens in the Mediterranean region $22,23,31, \operatorname{Iran}^{49}$ and $\operatorname{Oman}^{26}$ are based on quantitative structural geological constraints on reconstruction of back-arc extension, transform motion, shortening, and paleomagnetic data, in that order. The amount of shortening associated with stacking of orogenic nappes, and the reconstructed paleogeographic width of the platforms and basins from which these nappes were derived, is based on the amount of plate convergence constrained from the plate circuit that occurred during the underthrusting of the nappes as constrained by stratigraphic, metamorphic, and sedimentological data, whereby the amount of geologically documented shortening is used as a minimum value ${ }^{22,44}$. Reconstructions are tested against and iteratively improved using paleomagnetic constraints on vertical axis rotations, while obeying structural geological data. Intra-oceanic plate motion and original intraoceanic trench motion is constrained from paleomagnetic data on paleolatitude and paleo-dyke orientations preserved in supra-subduction zone ophiolites of Anatolia, Cyprus, Syria, and Oman ${ }^{26,31,50}$. 
341 ages of the metamorphic soles of ophiolites of Oman and Anatolia that consistently reveal $\sim 104 \mathrm{Ma}$

342 ages $^{18,30}$. Initiation of supra-subduction zone spreading follows from zircon $\mathrm{U} / \mathrm{Pb}$ ages from gabbros and 343 plagiogranites in the ophiolites, showing 96-95 Ma ages for Oman ${ }^{24}$ and $~ 92-90$ Ma ages for Anatolia 344 and Cyprus ${ }^{25,50}$. Predicted locations of subducted slabs at the moment of their breakoff, rotated in a 345 mantle reference frame ${ }^{51}$ are consistent with the locations of subducted slabs in the underlying mantle 346 constrained from seismic tomography ${ }^{32,52}$. Reconstructions were made in GPlates plate reconstruction 347 software ${ }^{53}$ and all rotation and shape files were provided as supplementary information to previous 348 papers $22,26,49,54$ available at http://www.geologist.nl/reconstructions/.

\section{Africa-North America plate motion}

351 We employed and adopted the results of kinematic investigations that used a best-fitting criteria ${ }^{55}$ and 352 statistical approach ${ }^{56}$ to compute the rotation parameters and their uncertainties for a set of plate-pairs. 353 For the post-CNS period, we adopted the North America-Africa kinematic solutions of Merkouriev and DeMets ${ }^{57}$ and Müller et al. ${ }^{58}$ The available Mesozoic kinematic solutions lack uncertainties, therefore we re-computed the M0, M10, M16r, M21r and M25r finite rotation parameters using the magnetic picks of Klitgord and Schouten ${ }^{59,60}$, for which we added fracture zone crossings based on satellite gravity data ${ }^{47}$. We also computed two internal rotation parameters for the Cretaceous Normal Superchron based on identification of magnetic anomalies (Q1 and Q2, Fig. 1 and Extended Data Fig. 1) that have arisen due to prominent changes in the behaviour of the geomagnetic field ${ }^{21}$. These features were previously used to compute the plate kinematics for the Cretaceous South Atlantic Ocean (Africa-South America Plates ${ }^{61}$ ) and resulted in opening ages of the Equatorial Atlantic that are consistent with global isotopic signatures

362 of benthic foraminifera ${ }^{56}$. We here follow a similar approach and internally date the Central Atlantic 363 CQZs by tracing these two magnetic features based on the available sea surface marine magnetic data (see 364 Extended Data Fig. 1). Satellite-derived gravity grids now have sufficient accuracy to trace seafloor fabric 365 (i.e., abyssal hills ${ }^{47}$ ), which provides additional independent constraint on the orientation of the isochrons. The new Q1 and Q2 Africa-North America kinematic solutions, with their 95\% uncertainty intervals, are 
367

shown in Extended Data Fig. 2 and Table 2. Most of the values of the statistical parameter $(\hat{\boldsymbol{\kappa}})$ are near one (see Extended Data Table 2) indicating that the uncertainty assigned to the data points (magnetic and fracture zone picks were assigned 4 and $5 \mathrm{~km}$, respectively) used to calculate the solutions were reasonable ${ }^{56}$. For anomaly Q2 the value of $\hat{\boldsymbol{\kappa}}$ is 5.5 indicating that the error values for the picks were overestimated by a factor of 2.3 . We note that rescaling the error estimates would make only a minor difference in the size of the uncertainty ellipse.

\section{North America- Eurasia plate motion}

We adopted the Eurasia-North America Cenozoic kinematic solutions of Merkouriev and DeMets ${ }^{41}$ and Gaina et al. ${ }^{62}$. The solution for C30y was interpolated using C25y and C31y solutions. The complex transition from continental rifting to ultra-slow seafloor spreading that occurred during the CNS prevent us from confidently recognizing the internal quiet zone anomalies. We thus adopted the M25 rotation pole of Torsvik et al. ${ }^{63}$ of which its location is based on seafloor data of the oldest magnetic anomaly and its angle was extended to bring the paleomagnetic poles of Eurasia and North America to fit. The rotation parameters of M21r, M16r, M10, M0, Q2, and Q1 were interpolated using C34 and M25 kinematic solutions $^{62-64}$. Since very slow extensional rates prevailed at this pre-seafloor spreading stage, the locations of the interpolated Mesozoic poles (and their uncertainties) have negligible effect on the resultant Africa-Eurasia finite rotation poles.

\section{Africa-North America-Eurasia plate circuit}

Mesozoic and Cenozoic motions of the African Plate relative to Eurasia Plate were calculated through the Africa-North America-Eurasia plate circuit. Finite rotations, and their uncertainties, were combined ${ }^{65}$ for the kinematic solutions (Fig. 3 and Extended Data Table 2) giving temporal resolution of $\sim 10 \mathrm{Ma}$ throughout the studied period (the last $156 \mathrm{Ma}$ ). The eastern-most part of Africa is now located on the Arabian Plate thus in order to calculate the trajectories and relative velocities of the area that is now part of Arabia, we added published Arabian-African rotation poles ${ }^{57}$. 
393

394

\section{References}

1. Torsvik, T. H., Müller, R. D., Van der Voo, R., Steinberger, B. \& Gaina, C. Global plate motion frames: toward a unified model. Rev. Geophys. 46, (2008).

2. Matthews, K. J., Seton, M. \& Müller, R. D. A global-scale plate reorganization event at 105-100 Ma. Earth Planet. Sci. Lett. 355-356, 283-298 (2012).

3. Müller, R. D. et al. Ocean basin evolution and global-scale plate reorganization events since Pangea breakup. Annu. Rev. Earth Planet. Sci. 44, 107-138 (2016).

4. Olierook, H. K. H. et al. Timing and causes of the mid-Cretaceous global plate reorganization event. Earth Planet. Sci. Lett. 534, 116071 (2020).

5. Rona, P. A. \& Richardson, E. S. Early Cenozoic global plate reorganization. Earth Planet. Sci. Lett. 40, 1-11 (1978).

6. O’Connor, J. M. et al. Constraints on past plate and mantle motion from new ages for the HawaiianEmperor Seamount Chain. Geochem. Geophys. Geosystems 14, 4564-4584 (2013).

7. Seton, M. et al. Ridge subduction sparked reorganization of the Pacific plate-mantle system 60-50 million years ago: Pacific plate-mantle reorganization. Geophys. Res. Lett. 42, 1732-1740 (2015).

8. Whittaker, J. M. et al. Major Australian-Antarctic plate reorganization at Hawaiian-Emperor bend time. Science 318, 83-86 (2007).

9. Cande, S. C. \& Stegman, D. R. Indian and African plate motions driven by the push force of the Reunion plume head. Nature 475, 47-52 (2011).

10. van Hinsbergen, D. J., Steinberger, B., Doubrovine, P. V. \& Gassmöller, R. Acceleration and deceleration of India-Asia convergence since the Cretaceous: Roles of mantle plumes and continental collision. J. Geophys. Res. Solid Earth 116, (2011).

11. van Hinsbergen, D. J. et al. A record of plume-induced plate rotation triggering seafloor spreading and subduction initiation. (2021).

12. Jagoutz, O., Royden, L., Holt, A. F. \& Becker, T. W. Anomalously fast convergence of India and Eurasia caused by double subduction. Nat. Geosci. 8, 475-478 (2015). 
419 13. Faccenna, C., Becker, T. W., Lallemand, S. \& Steinberger, B. On the role of slab pull in the Cenozoic 420 motion of the Pacific plate. Geophys. Res. Lett. 39, L03305 (2012).

421 14. Domeier, M. et al. Intraoceanic subduction spanned the Pacific in the Late Cretaceous-Paleocene. Sci. Adv. 3, eaao2303 (2017).

15. Buiter, S. J. \& Torsvik, T. H. A review of Wilson Cycle plate margins: A role for mantle plumes in continental break-up along sutures? Gondwana Res. 26, 627-653 (2014).

16. Stern, R. J. Subduction initiation: spontaneous and induced. Earth Planet. Sci. Lett. 226, 275-292 (2004).

17. Wu, J. T.-J. \& Wu, J. Izanagi-Pacific ridge subduction revealed by a 56 to 46 Ma magmatic gap along the northeast Asian margin. Geology 47, 953-957 (2019).

18. Guilmette, C. et al. Forced subduction initiation recorded in the sole and crust of the Semail Ophiolite of Oman. Nat. Geosci. 11, 688-695 (2018).

19. Agard, P., Jolivet, L., Vrielynck, B., Burov, E. \& Monie, P. Plate acceleration: the obduction trigger? Earth Planet. Sci. Lett. 258, 428-441 (2007).

20. Gradstein, F. M., Ogg, J. G., Schmitz, M. \& Ogg, G. The geologic time scale 2012. (Elsevier, 2012).

21. Granot, R., Dyment, J. \& Gallet, Y. Geomagnetic field variability during the Cretaceous Normal Superchron. Nat. Geosci. 5, 220-223 (2012).

22. van Hinsbergen, D. J. J. et al. Orogenic architecture of the Mediterranean region and kinematic reconstruction of its tectonic evolution since the Triassic. Gondwana Res. 81, 79-229 (2020).

23. Gürer, D., van Hinsbergen, D. J. J., Matenco, L., Corfu, F. \& Cascella, A. Kinematics of a former oceanic plate of the Neotethys revealed by deformation in the Ulukışla basin (Turkey). Tectonics 35, 2385-2416 (2016).

24. Rioux, M. et al. Tectonic development of the Samail ophiolite: High-precision U-Pb zircon geochronology and Sm-Nd isotopic constraints on crustal growth and emplacement. J. Geophys. Res. 118, 2085-2101 (2013).

25. Parlak, O. The Tauride ophiolites of Anatolia (Turkey): A review. J. Earth Sci. 27, 901-934 (2016). 
26. van Hinsbergen, D. J. J., Maffione, M., Koornneef, L. M. \& Guilmette, C. Kinematic and paleomagnetic restoration of the Semail ophiolite (Oman) reveals subduction initiation along an ancient Neotethyan fracture zone. Earth Planet. Sci. Lett. 518, 183-196 (2019).

27. Gaina, C. \& Jakob, J. Global eocene tectonic unrest: Possible causes and effects around the North American plate. Tectonophysics 760, 136-151 (2019).

28. Schellart, W. P. Andean mountain building and magmatic arc migration driven by subduction-induced whole mantle flow. Nat. Commun. 8, 1-13 (2017).

29. Tavani, S., Corradetti, A., Sabbatino, M., Seers, T. \& Mazzoli, S. Geological record of the transition from induced to self-sustained subduction in the Oman Mountains. J. Geodyn. 133, 101674 (2020).

30. Pourteau, A. et al. Thermal evolution of an ancient subduction interface revealed by Lu-Hf garnet geochronology, Halilbağı Complex (Anatolia). Geosci. Front. 10, 127-148 (2019).

31. Maffione, M., van Hinsbergen, D. J. J., de Gelder, G. I. N. O., van der Goes, F. C. \& Morris, A. Kinematics of Late Cretaceous subduction initiation in the Neo-Tethys Ocean reconstructed from ophiolites of Turkey, Cyprus, and Syria. J. Geophys. Res. 122, 3953-3976 (2017).

32. van der Meer, D. G., van Hinsbergen, D. J. J. \& Spakman, W. Atlas of the underworld: Slab remnants in the mantle, their sinking history, and a new outlook on lower mantle viscosity. Tectonophysics $\mathbf{7 2 3 ,}$ 309-448 (2018).

33. Warren, C. J., Parrish, R. R., Waters, D. J. \& Searle, M. P. Dating the geologic history of Oman's Semail ophiolite: insights from U-Pb geochronology. Contrib. Mineral. Petrol. 150, 403-422 (2005).

34. Holt, A. F., Royden, L. H. \& Becker, T. W. The dynamics of double slab subduction. Geophys. J. Int. 209, 250-265 (2017).

35. Čížková, H. \& Bina, C. R. Geodynamics of trench advance: Insights from a Philippine-Sea-style geometry. Earth Planet. Sci. Lett. 430, 408-415 (2015).

36. Pusok, A. E. \& Stegman, D. R. Formation and Stability of Same-Dip Double Subduction Systems. J. Geophys. Res. 124, 7387-7412 (2019). 
37. Király, Á., Funiciello, F., Capitanio, F. A. \& Faccenna, C. Dynamic interactions between subduction zones. Glob. Planet. Change 103501 (2021).

38. Dewey, J. F., Helman, M. L., Knott, S. D., Turco, E. \& Hutton, D. H. W. Kinematics of the western Mediterranean. Geol. Soc. Lond. Spec. Publ. 45, 265-283 (1989).

39. Rosenbaum, G., Lister, G. S. \& Duboz, C. Relative motions of Africa, Iberia and Europe during Alpine orogeny. Tectonophysics 359, 117-129 (2002).

40. Péron-Pinvidic, G., Manatschal, G., Minshull, T. A. \& Sawyer, D. S. Tectonosedimentary evolution of the deep Iberia-Newfoundland margins: Evidence for a complex breakup history. Tectonics 26, (2007).

41. Merkouriev, S. \& DeMets, C. A high-resolution model for Eurasia-North America plate kinematics since 20 Ma. Geophys. J. Int. 173, 1064-1083 (2008).

42. Lahondère, D. \& Guerrot, C. Datation Sm-Nd du métamorphisme éclogitique en Corse alpine: un argument pour l'existence au Crétacé supérieur d'une zone de subduction active localisée sous le bloc corso-sarde. Géologie Fr. 3-11 (1997).

43. Manzotti, P., Ballèvre, M., Zucali, M., Robyr, M. \& Engi, M. The tectonometamorphic evolution of the Sesia-Dent Blanche nappes (internal Western Alps): review and synthesis. Swiss J. Geosci. 107, 309-336 (2014).

44. Chertova, M. V., Spakman, W., Geenen, T., van den Berg, A. P. \& van Hinsbergen, D. J. J. Underpinning tectonic reconstructions of the western Mediterranean region with dynamic slab evolution from 3-D numerical modeling. J. Geophys. Res. 119, 5876-5902 (2014).

45. Hamai, L. et al. Towards subduction inception along the inverted North African margin of Algeria? Insights from thermo-mechanical models. Earth Planet. Sci. Lett. 501, 13-23 (2018).

46. van der Meer, D. G., Spakman, W., van Hinsbergen, D. J. J., Amaru, M. L. \& Torsvik, T. H. Towards absolute plate motions constrained by lower-mantle slab remnants. Nat. Geosci. 3, 36-40 (2010).

47. Sandwell, D. T., Müller, R. D., Smith, W. H. F., Garcia, E. \& Francis, R. New global marine gravity model from CryoSat-2 and Jason-1 reveals buried tectonic structure. Science 346, 65-67 (2014). 
48. Midtkandal, I. et al. The Aptian (Early Cretaceous) oceanic anoxic event (OAE1a) in Svalbard, Barents Sea, and the absolute age of the Barremian-Aptian boundary. Palaeogeogr. Palaeoclimatol. Palaeoecol. 463, 126-135 (2016).

49. McQuarrie, N. \& van Hinsbergen, D. J. J. Retrodeforming the Arabia-Eurasia collision zone: Age of collision versus magnitude of continental subduction. Geology 41, 315-318 (2013).

50. van Hinsbergen, D. J. J. et al. Tectonic evolution and paleogeography of the Kırşehir Block and the Central Anatolian Ophiolites, Turkey. Tectonics 35, 983-1014 (2016).

51. Doubrovine, P. V., Steinberger, B. \& Torsvik, T. H. Absolute plate motions in a reference frame defined by moving hot spots in the Pacific, Atlantic, and Indian oceans. J. Geophys. Res. 117, (2012).

52. Gürer, M. D. Subduction evolution in the Anatolian region: the rise, demise, and fate of the Anadolu Plate. (Utrecht University, The Netherlands, 2017).

53. Boyden, J. A. et al. Next-generation plate-tectonic reconstructions using GPlates. in Geoinformatics: Cyberinfrastructure for the Solid Earth Sciences (eds. Keller, G. R. \& Baru, C.) 95-113 (Cambridge University Press, 2011).

54. Gürer, D. \& van Hinsbergen, D. J. J. Diachronous demise of the Neotethys Ocean as a driver for noncylindrical orogenesis in Anatolia. Tectonophysics 760, 95-106 (2019).

55. Hellinger, S. J. The uncertainties of finite rotations in plate tectonics. J. Geophys. Res. 86, 9312-9318 (1981).

56. Royer, J.-Y. \& Chang, T. Evidence for relative motions between the Indian and Australian Plates during the last 20 m.y. from plate tectonic reconstructions: Implications for the deformation of the Indo-Australian Plate. J. Geophys. Res. 96, 11779-11802 (1991).

57. Merkouriev, S. \& DeMets, C. High-resolution estimates of Nubia-North America plate motion: 20 Ma to present. Geophys. J. Int. 196, 1281-1298 (2013).

58. Müller, R. D., Royer, J.-Y., Cande, S. C., Roest, W. R. \& Maschenkov, S. New constraints on the Late Cretaceous/Tertiary plate tectonic evolution of the Caribbean. in Sedimentary Basins of the World (ed. Mann, P.) vol. 4 33-59 (Elsevier, 1999). 
59. Klitgord, K. D. \& Schouten, H. Plate kinematics of the central Atlantic. in The Western North Atlantic Region (eds. Vogt, P. R. \& Tucholke, B. E.) 351-378 (Geology of North America, 1986). doi:10.1130/DNAG-GNA-M.351.

60. Seton, M. et al. Community infrastructure and repository for marine magnetic identifications. Geochem. Geophys. Geosystems 15, 1629-1641 (2014).

61. Granot, R. \& Dyment, J. The Cretaceous opening of the South Atlantic Ocean. Earth Planet. Sci. Lett. 414, 156-163 (2015).

62. Gaina, C., Roest, W. R. \& Müller, R. D. Late Cretaceous-Cenozoic deformation of northeast Asia. Earth Planet. Sci. Lett. 197, 273-286 (2002).

63. Torsvik, T. H., Van der Voo, R., Meert, J. G., Mosar, J. \& Walderhaug, H. J. Reconstructions of the continents around the North Atlantic at about the 60th parallel. Earth Planet. Sci. Lett. 187, 55-69 (2001).

64. Doubrovine, P. V. \& Tarduno, J. A. A revised kinematic model for the relative motion between Pacific oceanic plates and North America since the Late Cretaceous. J. Geophys. Res. 113, B12101 (2008).

65. Chang, T., Stock, J. \& Molnar, P. The rotation group in plate tectonics and the representation of uncertainties of plate reconstructions. Geophys. J. Int. 101, 649-661 (1990). 


\section{Extended Data figures and tables}

2 Table 1. The source of the rotation parameters used in this study.

\begin{tabular}{|c|c|c|c|c|}
\hline Magnetic anomaly & Age [Ma] & North America - Africa & $\begin{array}{l}\text { North America - } \\
\text { Eurasia }\end{array}$ & Age source \\
\hline C5n.1n (C5n.1y) & 9.786 & Merkouriev, 2014 (ref. $^{1}$ ) & $\begin{array}{l}\text { Merkouriev, } 2008 \\
\left(\text { ref. }^{2}\right)\end{array}$ & \multirow{8}{*}{ Ogg 2012 (ref. $\left.^{3}\right)$} \\
\hline C6no & 19.722 & Merkouriev, 2014 (ref. $^{1}$ ) & $\begin{array}{l}\text { Merkouriev, } 2008 \\
\left(\text { ref. }^{2}\right)\end{array}$ & \\
\hline C13n (C13y) & 33.157 & Müller 1999 (ref. $^{4}$ ) & Gaina 2002 (ref. $^{5}$ ) & \\
\hline C20no (C20o) & 43.43 & $\begin{array}{l}\left.\text { Müller } 1999 \text { (ref. }^{4}\right) \\
\text { (interpolated) }\end{array}$ & Gaina $2002\left(\right.$ ref. $\left.^{5}\right)$ & \\
\hline C24n.3no (C24o) & 53.93 & $\begin{array}{l}\text { Müller } 1999 \text { (ref. }^{4} \text { ) } \\
\text { (interpolated) }\end{array}$ & Gaina 2002 (ref. $\left.{ }^{5}\right)$ & \\
\hline C30n (C30y) & 66.398 & Müller 1999 (ref. $\left.{ }^{4}\right)$ & $\begin{array}{l}\text { Gaina } 2002 \text { (ref. }^{5} \text { ) } \\
\text { (interpolated) }\end{array}$ & \\
\hline $\mathrm{C} 33 \mathrm{o}$ & 79.9 & Müller 1999 (ref. $^{4}$ ) & Gaina $2002\left(\right.$ ref. $\left.^{5}\right)$ & \\
\hline C34n (C34) & 83.64 & Müller 1999 (ref. $^{4}$ ) & Gaina 2002 (ref. $^{5}$ ) & \\
\hline Q1 & 92 & This study & Interpolated & \multirow{2}{*}{ Granot $2012\left(\right.$ ref. $\left.^{6}\right)$} \\
\hline Q2 & 108 & This study & Interpolated & \\
\hline M0 & $\begin{array}{c}125.93 \\
(120.95)\end{array}$ & This study & Interpolated & \multirow{5}{*}{$\begin{array}{l}\text { Ogg } 2012 \text { (ref. }^{3} \text { ) } \\
\text { Malinverno } 2012 \\
\text { (ref. }^{7} \text { ) }\end{array}$} \\
\hline M10 & $\begin{array}{r}133.58 \\
(130.43)\end{array}$ & This study & Interpolated & \\
\hline M16r & $\begin{array}{r}141.64 \\
(138.82)\end{array}$ & This study & Interpolated & \\
\hline M21r & $\begin{array}{c}149.35 \\
(143.89)\end{array}$ & This study & Interpolated & \\
\hline $\mathrm{M} 25 \mathrm{r}$ & $\begin{array}{c}156.42 \\
(151.36)\end{array}$ & This study & Torsvik $2001\left(\right.$ ref. $\left.^{8}\right)$ & \\
\hline
\end{tabular}



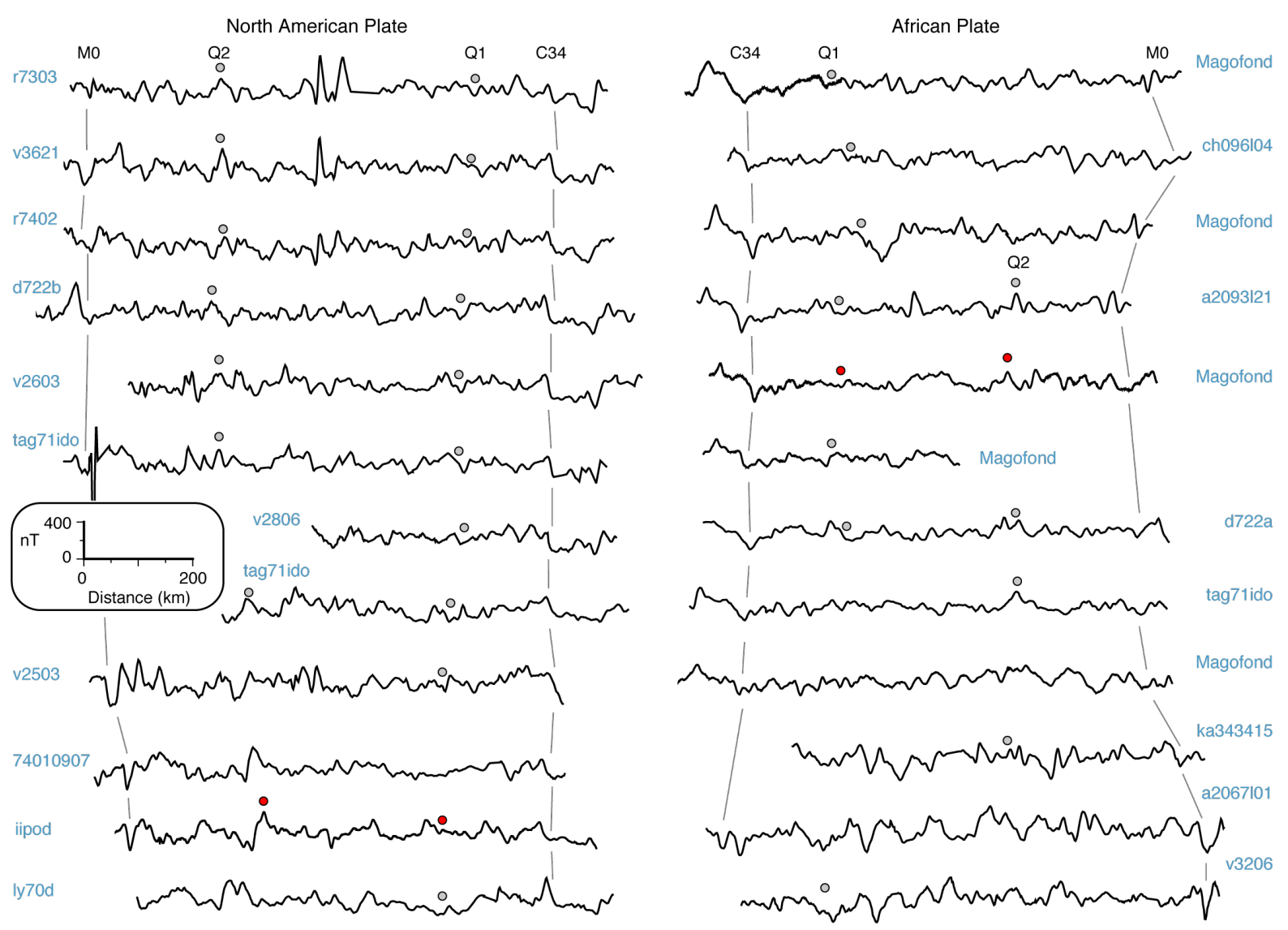

Figure 1. Magnetic anomaly sea surface representative profiles used for the kinematic analysis of the Central Atlantic quiet zones ordered from north (top) to south (bottom). Magnetic identification of Q1 and Q2 are shown in two profiles with red circles ${ }^{6}$. These anomalies were then traced outward into the other Central Atlantic magnetic profiles ${ }^{6}$ (gray circles), using both the magnetic anomalies backed by the vertical gradient of the gravity field (Fig. 1) that provide independent constraints on the crustal structure and seafloor fabric. Sources of data are the National Centers for Environmental Information (NCEI) and Ifremer (MAGOFOND cruise ${ }^{9}$ ). 


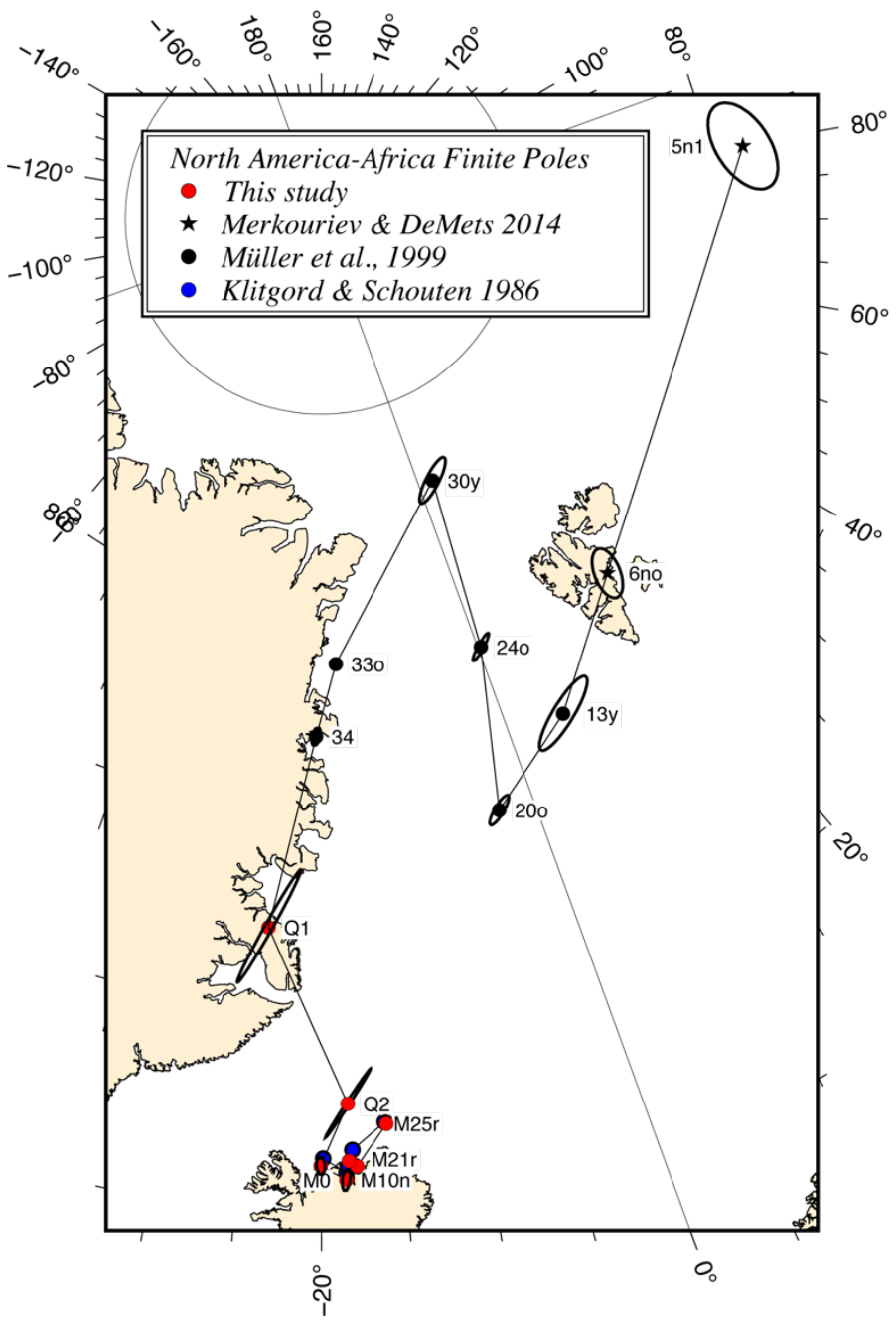

24 Figure 2. North America-Africa finite rotation poles and their 95\% confidence ellipses.

Table 2. Finite rotations and covariance matrices for the relative motion of Africa relative to

27 North America (fixed). The covariance matrix is given by the formula $\frac{1}{\hat{k}} *$

$28(a b c b d e c e f) * 10^{-g}$ radians $^{2}$.

29

\begin{tabular}{|c|c|c|c|c|c|c|c|c|c|c|c|}
\hline $\begin{array}{l}\text { Mag. } \\
\text { Ano }\end{array}$ & $\begin{array}{l}\text { Lat } \\
\left({ }^{\circ} \mathbf{N}\right)\end{array}$ & $\begin{array}{c}\text { Long } \\
\left({ }^{\circ} \mathrm{E}\right)\end{array}$ & $\begin{array}{c}\text { Angle } \\
\left({ }^{\circ}\right)\end{array}$ & $\hat{\kappa}$ & $\mathbf{a}$ & $\mathbf{b}$ & c & $\begin{array}{l}\mathrm{d} \\
\end{array}$ & $\bar{e}$ & $\mathbf{f}$ & $\bar{g}$ \\
\hline Q1 & 71.98 & -24.26 & 35.88 & 1.81 & 2.48 & -4.05 & 2.71 & 6.69 & $\begin{array}{l}-4.49 \\
\end{array}$ & 3.02 & 5 \\
\hline Q2 & 67.64 & -18.30 & 46.76 & 5.56 & 3.70 & -7.12 & 4.82 & 13.77 & -9.33 & 6.34 & 5 \\
\hline M0 & 66.12 & -20.05 & 54.41 & 0.78 & 10.52 & -7.47 & 1.91 & 8.69 & -4.65 & 3.87 & 7 \\
\hline M10 & 66.77 & -18.52 & 57.58 & 0.50 & 9.90 & -9.64 & 5.14 & 11.94 & -7.27 & 5.15 & 7 \\
\hline M16r & 66.23 & -18.33 & 59.70 & 1.02 & 9.86 & -11.08 & 5.37 & 15.25 & -8.44 & 5.24 & 7 \\
\hline $\mathrm{M} 21 \mathrm{r}$ & 66.10 & -17.85 & 62.12 & 2.15 & 13.90 & -9.53 & 1.74 & 9.89 & -4.12 & 3.07 & 7 \\
\hline M25r & 67.10 & -15.90 & 64.70 & 1.78 & 7.60 & -6.31 & 1.39 & 8.77 & -4.21 & 3.20 & 7 \\
\hline
\end{tabular}




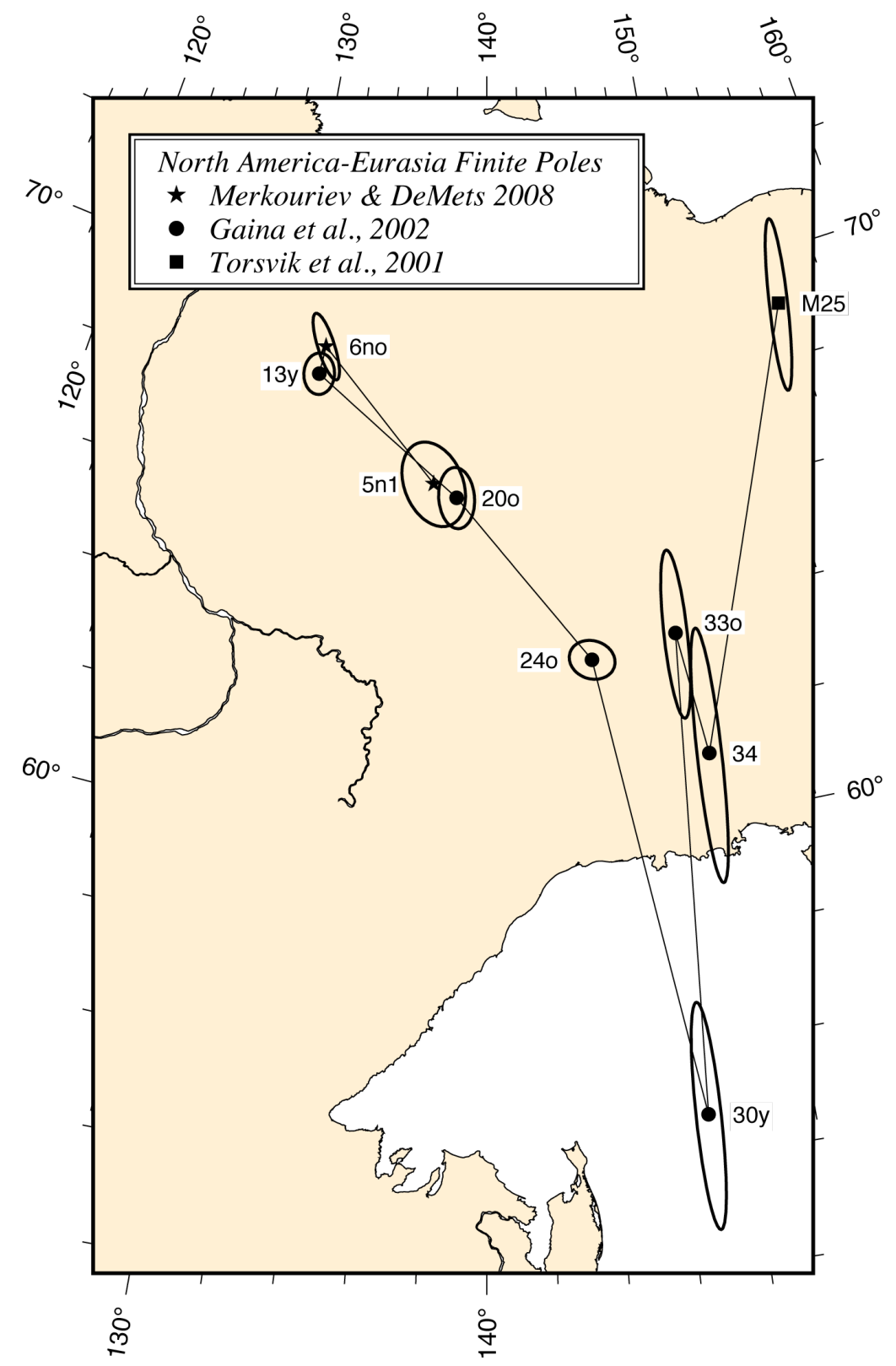

32 Figure 3. North America- Eurasia finite rotation poles and their 95\% confidence ellipses. 

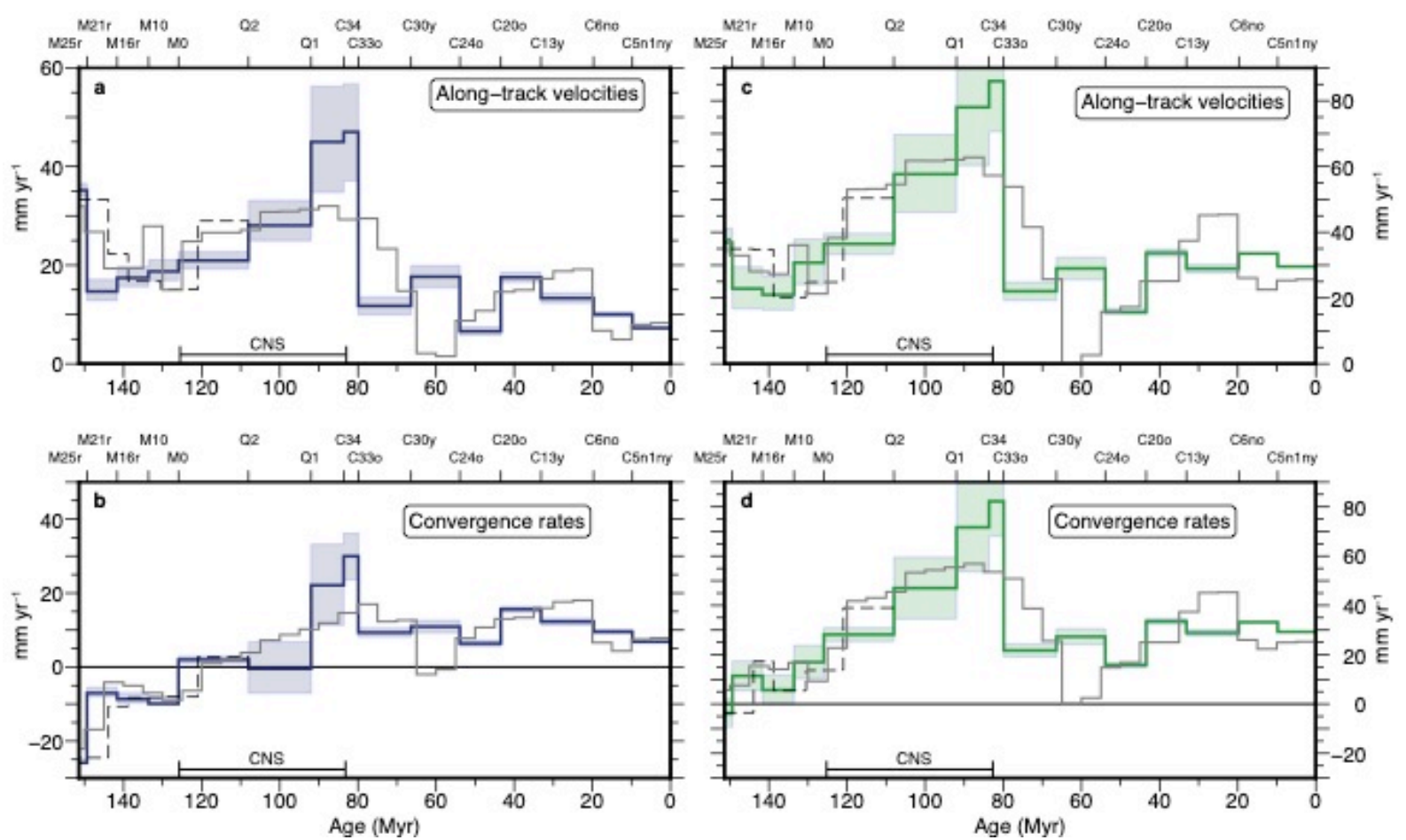

\section{$34 \quad$ Figure 4.}

35 Velocities along-track (a,c) and convergence rates $(\mathbf{b}, \mathbf{d})$ for the trajectories shown in Fig. $3 b$

36 (a-b and c-d are calculated using the western and eastern trajectory, respectively). The velocities

37 were calculated using the geomagnetic polarity time scale of $\mathrm{Ogg}^{3}$. Dashed lines delineate the

38 Mesozoic rates when using the Malinverno et al. ${ }^{7}$ timescale. Grey lines show previous estimates

39 of convergence rates inferred from interpolating plate motion change across the entire

40 Cretaceous Normal Superchron ${ }^{10}$. Blue shadings show the $1 \sigma$ uncertainties that were calculated

41 based on the uncertainties of the reconstructed points. Convergence rates are the margin-

42 orthogonal components of the relative motions, calculated along northward (b) or $\mathrm{N} 30^{\circ} \mathrm{E}$ (d)

43 direction. 


\section{References}

1. Merkouriev, S. \& DeMets, C. High-resolution Neogene reconstructions of Eurasia-North America Plate motion. Geophys. J. Int. 198, 366-384 (2014).

2. Merkouriev, S. \& DeMets, C. A high-resolution model for Eurasia-North America plate kinematics since 20 Ma. Geophys. J. Int. 173, 1064-1083 (2008).

3. Ogg, J. G. Geomagnetic polarity time scale. in The Geologic Time Scale 2012 edited by Gradstein, F. M., Ogg, J. G., Schmitz, M. D. and Ogg, G. M. 85-114 (Elsevier, 2012).

4. Müller, R. D., Royer, J.-Y., Cande, S. C., Roest, W. R. \& Maschenkov, S. New constraints on the Late Cretaceous/Tertiary plate tectonic evolution of the Caribbean. in Sedimentary Basins of the World (ed. Mann, P.) vol. 4 33-59 (Elsevier, 1999).

5. Gaina, C., Roest, W. R. \& Müller, R. D. Late Cretaceous-Cenozoic deformation of northeast Asia. Earth Planet. Sci. Lett. 197, 273-286 (2002).

6. Granot, R., Dyment, J. \& Gallet, Y. Geomagnetic field variability during the Cretaceous Normal Superchron. Nat. Geosci. 5, 220-223 (2012).

7. Malinverno, A., Hildebrandt, J., Tominaga, M. \& Channell, J. E. T. M-sequence geomagnetic polarity time scale (MHTC12) that steadies global spreading rates and incorporates astrochronology constraints. J. Geophys. Res. 117, (2012).

8. Torsvik, T. H., Van der Voo, R., Meert, J. G., Mosar, J. \& Walderhaug, H. J. Reconstructions of the continents around the North Atlantic at about the 60th parallel. Earth Planet. Sci. Lett. 187, 55-69 (2001).

9. Dyment J., Gallet Y. MAGOFOND cruise, RV Le Suroît, (2005), https://doi.org/10.17600/5020060, see cruise webpage: https://campagnes.flotteoceanographique.fr/campagnes/5020060/

10. Rosenbaum, G., Lister, G. S. \& Duboz, C. Relative motions of Africa, Iberia and Europe during Alpine orogeny. Tectonophysics 359, 117-129 (2002). 